\title{
Biological Responses of Antiprogestins in Mammary Gland, Uterus and Seminal Vesicles of Prepubertal Intact and Adult Gonadectomized Mice
}

\author{
E. KÖHLEROVÁ, J. KOTANOVÁ, J. ŠKARDA \\ Institute of Animal Physiology and Genetics, Academy of Sciences of the Czech Republic, Prague \\ Received December 1, 2005 \\ Accepted March 16, 2006
}

\begin{abstract}
Köhlerová E., J. Kotanová, J. Škarda: Biological Responses of Antiprogestins in Mammary Gland, Uterus and Seminal Vesicles of Prepubertal Intact and Adult Gonadectomized Mice. Acta Vet. Brno 2006, 75: 319-328.

The present study tested and compared the antiproliferative and proliferative activities of three antiprogestins on four separate mouse model systems: prepubertal intact and adult ovariectomized (OVX) females, prepubertal intact and adult castrated males. In prepubertal intact males and females and adult castrated males, norethindrone acetate (NA; a synthetic steroid exhibiting progestational and estrogenic activities)- stimulated mammary growth was decreased by antiprogestins: more by RU 46556 (RU) than RU 38486 (MI) and onapristone (ON) . In adult OVX females the inhibitory effect of RU and MI was lower than that of ON. Uterine weights were not significantly decreased by MI, were significantly decreased by RU at a lower daily dose $(50 \mu \mathrm{g})$ but not affected by a high $(500 \mu \mathrm{g})$ dose. Seminal vesicle weights were increased by RU but not affected by MI in both NA-treated prepubertal and adult castrated males. In adult castrated but not in prepubertal males ON decreased seminal vesicle weights. In $17 \beta$-estradiol (E) plus progesterone (Prog)-treated animals of all four model systems, RU $(100 \mu \mathrm{g} / \mathrm{d})$ acted additively with a submaximal daily dose $(10 \mu \mathrm{g})$ of antiestrogen ICI 182, 780 (ICI) to produce a lower mammary gland growth rate than ICI alone. In uterus, however, no significant effect of a combination of ICI plus RU was noted when compared with ICI alone. In general, our assay could serve as an in vivo tool for the detection of steroid hormone agonist and antagonist activities of newly synthesized analogs of steroid hormones, and natural and man-made chemicals and extracts of environmental samples.
\end{abstract}

Mifepristone, RU 46556, onapristone, growth, uterus, seminal vesicles, mice, bioassay

Progesterone (Prog) is a key modulator of the cellular processes that are required for the development and maintenance of reproductive function. Produced primarily by ovarian granulosa cells, it mediates its biological activity throughout the body by interacting with specific high- affinity nuclear Prog receptors (PR) proteins located in target cell nuclei. In the absence of ligand, PR resides in the nucleus associated with a high molecular weight complex comprising heat shock proteins (Hsps) and possibly other proteins. Upon binding of Prog, PR undergoes a conformational change and initiates the signal transduction cascade by phosphorylation, promoting displacement of Hsps, dimerization, nuclear translocation, the interaction of the receptor dimer with specific Prog response elements (PREs) located within target gene promoters and recruitment of adaptor proteins, which allow PR to interact productively with the general transcription apparatus (McDonnell 1995). The magnitude of the positive or negative effects of the DNA bound receptor on transcription is subsequently determined by the structure of the PR complex, promoter environment and the expression level of the receptor associated proteins such as coactivators and corepressors. Thus, PR may not function in an equivalent manner in all cells ( S a th y a et al. 2002). There is now ample evidence that a steroid hormone may interact with various isoforms or variations of nuclear receptors. Thus, Prog may be bound to either PR A, B or C. All forms of PR are derived from a single gene as a consequence of alternate initiation of transcription

Address for correspondence:

Doc. MVDr. Josef Škarda, DrSc.

Institute of Animal Physiology and Genetics,

Academy of Sciences of the Czech Republic

Vídeňská 1083, 14220 Praha 4, Czech Republic
Phone: +420267090505

Fax: +420267090500

E-mail: skarda@iapg.cas.cz

http://www.vfu.cz/acta-vet/actavet.htm 
from distinct promoters (Kastner et al. 1990; Wei et al. 1996; Giangrande et al. 1997). PR-B is primarily involved in mediating the positive transcriptional responses to Prog, whereas PR-A is, with few exceptions, inactive under the same conditions and moreover in several systems the primary function of PR-A appears to be a negative regulator of PRB mediated transcription. PR-C can modulate the transcriptional activity of both PR-A and PR-B. Significantly, it was observed also that the transcriptional activity of the glucocorticoid, mineralocorticoid, androgen and estrogen receptors (ER) was negatively regulated by PR-A (V e geto et al. 1993). The contrasting activities of PRs suggest that the relative tissue distributions of the three receptor isoforms are a major determinant of the pleitropic biological effects of progestins and antiprogestins. Antiprogestins compete with Prog for binding to PR without inducing complete signal transduction. Since inhibition of transcriptional activity by steroid receptor antagonist may vary, some antihormones have a partial agonistic activity. In addition, expression of agonistic and antagonistic activity varies between hormone dependent tissues, depending on the spectrum of locally available nuclear receptors, coactivators and corepressors.An active genomic Prog response mechanism has been found to coexist with the nongenomic one in reproductive tissues (Revelli et al. 1998).

Detection and characterization of agents as steroid hormone agonist and antagonist necessitates the integrated use of in vivo and in vitro assays. Recently, we have tested and compared four mouse model systems the prepubertal intact female, the adult ovariectomized (OVX), the prepubertal male and adult castrated male for determination of steroid hormone agonist and antagonist activities in vivo. It was based on simultaneous evaluation of a combination of several endpoints (mammary, uterine, seminal vesicles and spleen growth responses). The changes in organ growth were determined following administration of a tested compound alone or in combination with hormones known to stimulate or inhibit organ growth (Šk karda 2002abc, 2003; Hufriy et al. 2003; Köhlerová and Škarda 2004; Kotanová et al. 2005; Škarda and Köhlerová 2006).

The purpose of the present experiments was to test the ability of four model systems to evaluate the proliferative and antiproliferative activities of three antiprogestins and a combination of antiprogestin and antiestrogen.

\section{Materials and Methods}

Materials

Progesterone (Prog), 17b estradiol (E), norethindrone acetate (NA), t-amylalcohol and methylsalicylate were purchased from Sigma-Aldrich (Prague, Czech Republic). 2,2,2-tribromoethanol (Fluka Chemie AG, Buchs, Switzerland) was bought for preparation of Avertin. Hematoxylin was bought from Merck (Darmstadt, Germany). Steroidal antiestrogen Faslodex (ICI 182,780; ICI) was obtained both as a gift from Zeneca Pharmaceuticals, Maclesfield (UK) and as goods purchased from Tocris Cookson Ltd., Northpoint Fourth Way Avonmonth (UK). Antiprogestins RU 38486 (Mifepristone; MI) and RU 46556 (RU) were gifts from the Centre de Recherches Rousell-Uclaf, Romainville (France) and ZK 98.299 (Onapristone; ON) was a gift from Schering AG, Berlin (Germany). Hormones and antihormones were dissolved in oily vehicle (Köhle rová and Škarda 2004). Heavyduty Kapak/Scotchpak heat sealable pouches (Stock no. 502) were purchased from KAPAK Corporation (Minneapolis, MN, U.S.A).

Animals

Outbred $\mathrm{C} 3 \mathrm{H}$ mice were from our own colony. Animals were maintained on a $12 \mathrm{~h}$ light/12 h dark lighting schedule (light 6.00-18.00 h), fed pelleted nutritionally complete diet (TOP Velas, Lysá n. Labem, Czech Republic). The diet and water were allowed ad libitum and the daily routine in the vivarium was constant. To minimize variation of the dose-response relationship of injected hormones, all young animals were weighed at the age of 18 days and only animals weighing $8.5 \pm 1 \mathrm{~g}$ were randomly divided into the treated groups or used for further breeding.

Young intact (at 18 days of age) and adult gonadectomized (females were ovariectomized at 22-24 days of age, i.e. before the allometric growth phase of the mammary gland, males were castrated at 30-35 days of age) mice were used. Gonadectomy was performed under Avertin anesthesia and administration of compounds began 15-20 days after operation. Animals were injected $50 \mu \mathrm{l}$ of oily vehicle (control) or a compound in oily vehicle s.c. for 10 or 15 days in females and males, respectively. Doses of hormones are expressed in $\mu \mathrm{g}$ per day pro toto. The mean 
weight of young intact females was $11 \mathrm{~g}$, young intact males $13 \mathrm{~g}$, adult OVX females $21 \mathrm{~g}$, adult castrated males $24 \mathrm{~g}$. The period of hormone treatment is long enough to stimulate/inhibit mammary gland and uterine growth and mimic exposure to a constant level of a compound for a significant phase of life much like that achieved in animals exposed to hormonally active xenobiotics. At the end of treatment and within $24 \mathrm{~h}$ of the last hormone administration, animals were weighed and killed. The first pair of inguinal mammary fat pads was removed for whole-mount. Mammary fat pads of males that showed no detectable mammary gland (10\%) were excluded from the data set; not detectable mammary gland was usually from one side, mammary gland from the other side was used for evaluation. Uteri and seminal vesicles were dissected out and weighed wet on a precision electronic balance. Weights of uteri and seminal vesicles before expressing the fluid secretion are presented. All experimental procedures were conducted in compliance with the highest standards of humane animal care and approved by the Ethical Committee of the Institute of Animal Physiology and Genetics of the Academy of Sciences.

Mammary whole-mount preparation and quantitative mammary histology

Mammary fat pads spread as flat as possible, put into Carnoy's fixative, defatted in acetone, stained in hematoxylin, destained in $1 \% \mathrm{HCl}$, blued in $0.1 \% \mathrm{NH}_{4} \mathrm{OH}$, dehydrated through graded alcohols, cleared in toluene and stored in methyl salicylate in a heavy duty heat sealed pouches (Köhlerová and Škarda, 2004).

A modification of Chalkley's morphological analysis was used to determine the percentage area of the mammary fat pad occupied by mammary epithelial structures on enlarged $(\times 12)$ photographs of the mammary whole-mount preparation (Škarda 2003).

\section{Statistical analysis}

All data represent mean \pm SEM. Statistically significant difference was determined by ANOVA, followed by the Bonferroni test for individual comparisons of the mean values.

\section{Results}

\section{Effects of RU, MI and ON in females}

In young intact females RU caused a significant $51 \%, 47 \%$, and $69 \%$ inhibitions of NA $(12.5 \mu \mathrm{g} / \mathrm{d})$ - stimulated mammary growth at 50,100 and $500 \mu \mathrm{g}$ doses, respectively. MI, on the other hand, at the same doses caused only $36 \%, 34 \%$ and $38 \%$ decreases in mammary growth (Fig. 1).
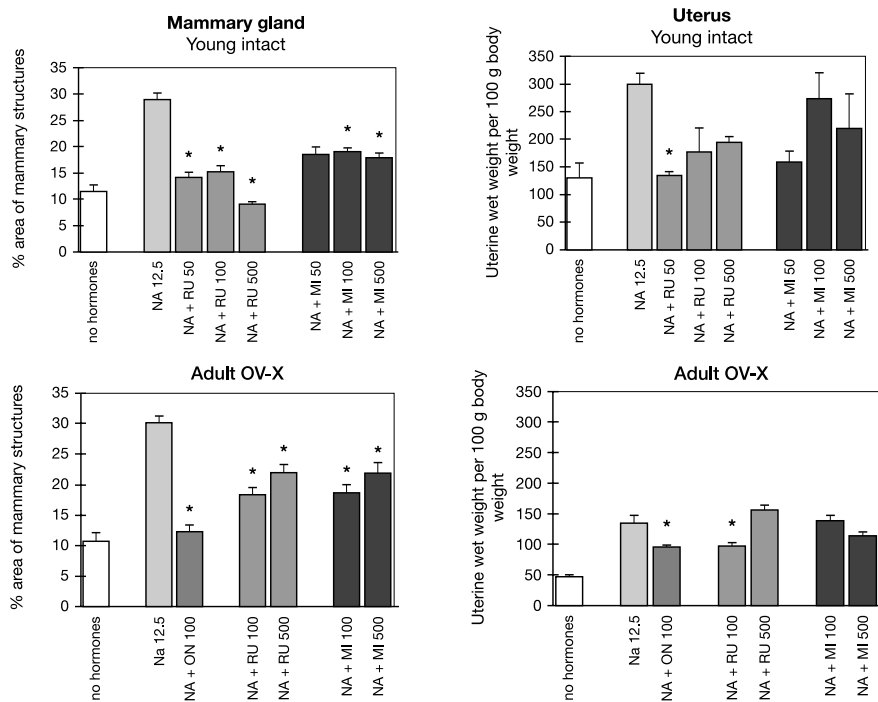

Fig. 1. Effects of progesterone antagonists RU 46556 (RU), mifepristone (MI) and onapristone (ON) on norethindrone acetate (NA) stimulated mammary and uterine growth in female mice. Prepubertal (day 18 of age) and adult OVX (ovariectomized at 22-24 days of age) females (4-5 per group) received s.c. injections of vehicle (no hormones) or different daily doses of hormones (given in $\mu \mathrm{g} / \mathrm{d}$ ) for 10 days. Results represent the mean \pm SEM.

$* p<0.05$ 
RU at the lowest daily dose $(50 \mu \mathrm{g})$ decreased uterine weight significantly by $55 \%$, whereas doses of 100 and $500 \mu \mathrm{g}$ non- significantly. MI at all used doses decreased uterine weight non-significantly, obviously due to high variability in uterine weights.

In adult OVX females RU, MI and ON caused significant inhibitions of NA-stimulated mammary growth. ON and RU at daily dose $100 \mu \mathrm{g}$ caused significant decreases in uterine weights, whereas MI had no effect.

Effects of RU, MI and ON in males

In prepubertal intact males, ON had no significant effect at the lowest daily dose $(50 \mu \mathrm{g})$ used and caused $35 \%$ and $83 \%$ decreases in NA $(12.5 \mu \mathrm{g} / \mathrm{d})$ stimulated mammary growth at doses of 100 and $500 \mu \mathrm{g} / \mathrm{d}$, respectively. RU caused $83 \%, 85 \%$, and $93 \%$ and similarly MI caused a 79\%, 86\% and 84\% inhibitions of NA stimulated mammary growth at doses of 50, 100 , and $500 \mu \mathrm{g} / \mathrm{d}$, respectively (Table 1 ). When mammary growth was stimulated by NA at a daily dose of $25 \mu \mathrm{g}$, RU caused $90 \%, 89 \%$, and $91 \%$ inhibitions, whereas MI caused $87 \%, 82 \%$, and $85 \%$ inhibitions of NA stimulated mammary growth.

Table 1. Effect of progesterone antagonists ON, RU and MI on NA- stimulated mammary growth and seminal vesicle and spleen weights in prepubertal intact $\mathrm{C} 3 \mathrm{H}$ male mice

\begin{tabular}{|c|c|c|c|}
\hline $\begin{array}{l}\text { Hormonal } \\
\text { treatment } \\
\left(\mu \mathrm{g} \cdot \mathrm{d}^{-1}\right)\end{array}$ & $\begin{array}{c}\text { The } \% \text { area of mammary fat } \\
\text { pad occupied by mammary } \\
\text { epithelial structures }\end{array}$ & $\begin{array}{c}\text { Seminal vesicle weights } \\
\left.\text { (mg.100 } \mathrm{g}^{-1} \text { of body weight }\right)\end{array}$ & $\begin{array}{c}\text { Spleen weight } \\
\text { (mg.100 } \mathrm{g}^{-1} \text { of body weight) }\end{array}$ \\
\hline 0 & $1.0 \pm 0.1(30)$ & $130.6 \pm 12.1(15)$ & $557.4 \pm 20.5(15)$ \\
\hline NA 12.5 & $17.5 \pm 1.4^{\mathrm{A}}(20)$ & $143.5 \pm 11.0^{\mathrm{A}}(8)$ & $575.7 \pm 34.3^{\mathrm{A}}(9)$ \\
\hline $\mathrm{NA}+\mathrm{ON} 50$ & $13.3 \pm 2.9^{\mathrm{A}}(8)$ & $86.9 \pm 9.8^{\mathrm{A}}(5)$ & $577.8 \pm 18.9^{\mathrm{A}}(5)$ \\
\hline $\mathrm{NA}+\mathrm{ON} 100$ & $11.3 \pm 1.0^{\mathrm{B}}(10)$ & $76.6 \pm 4.7^{\mathrm{A}}(5)$ & $562.3 \pm 31.3^{\mathrm{A}}(5)$ \\
\hline $\mathrm{NA}+\mathrm{ON} 500$ & $2.9 \pm 0.4^{\mathrm{B}}(10)$ & $78.9 \pm 7.4^{A}(5)$ & $669.0 \pm 35.3^{\mathrm{A}}(5)$ \\
\hline NA 12.5 & $17.5 \pm 1.4^{\mathrm{A}}(20)$ & $143.5 \pm 11.0^{\mathrm{A}}(8)$ & $575.7 \pm 34.3^{\mathrm{A}}(9)$ \\
\hline $\mathrm{NA}+\mathrm{RU} 50$ & $2.9 \pm 0.3^{\mathrm{B}}(14)$ & $153.8 \pm 21.6^{\mathrm{A}}(8)$ & $623.2 \pm 51.5^{\mathrm{A}}(8)$ \\
\hline $\mathrm{NA}+\mathrm{RU} 100$ & $2.7 \pm 0.3^{\mathrm{B}}(22)$ & $159.3 \pm 16.6^{\mathrm{A}}(11)$ & $537.2 \pm 29.6^{\mathrm{A}}(11)$ \\
\hline $\mathrm{NA}+\mathrm{RU} 500$ & $1.3 \pm 0.2^{\mathrm{B}}(20)$ & $234.2 \pm 17.8^{\mathrm{B}}(10)$ & $470.1 \pm 15.6^{\mathrm{A}}(10)$ \\
\hline NA 12.5 & $17.5 \pm 1.4^{\mathrm{A}}(20)$ & $143.5 \pm 11.0^{\mathrm{A}}(8)$ & $575.7 \pm 34.3^{\mathrm{A}}(9)$ \\
\hline $\mathrm{NA}+\mathrm{MI} 50$ & $3.7 \pm 0.5^{\mathrm{B}}(9)$ & $170.9 \pm 13.1^{\mathrm{A}}(5)$ & $570.1 \pm 42.0^{\mathrm{A}}(5)$ \\
\hline $\mathrm{NA}+\mathrm{MI} 100$ & $2.5 \pm 0.6^{\mathrm{B}}(11)$ & $217.9 \pm 12.6^{\mathrm{A}}(5)$ & $481.3 \pm 15.9^{\mathrm{A}}(5)$ \\
\hline $\mathrm{NA}+\mathrm{MI} 500$ & $2.8 \pm 0.9^{\mathrm{B}}(10)$ & $128.0 \pm 18.9^{\mathrm{A}}(5)$ & $552.5 \pm 46.0^{\mathrm{A}}(5)$ \\
\hline NA 25 & $32.9 \pm 2.3^{\mathrm{A}}(10)$ & $71.8 \pm 15.9^{\mathrm{A}}(5)$ & $672.1 \pm 39.0^{\mathrm{A}}(5)$ \\
\hline $\mathrm{NA}+\mathrm{RU} 50$ & $3.3 \pm 0.4^{\mathrm{B}}(11)$ & $142.6 \pm 12.0^{\mathrm{A}}(6)$ & $544.9 \pm 45.1^{\mathrm{A}}(5)$ \\
\hline $\mathrm{NA}+\mathrm{RU} 100$ & $3.6 \pm 0.5^{\mathrm{B}}(12)$ & $209.6 \pm 12.9^{\mathrm{B}}(5)$ & $560.0 \pm 18.6^{\mathrm{A}}(6)$ \\
\hline $\mathrm{NA}+\mathrm{RU} 500$ & $2.9 \pm 0.7^{\mathrm{B}}(10)$ & $283.7 \pm 20.7^{\mathrm{B}}(5)$ & $499.2 \pm 10.1^{\mathrm{B}}(5)$ \\
\hline NA 25 & $32.9 \pm 2.3^{\mathrm{A}}(10)$ & $71.8 \pm 15.9^{\mathrm{A}}(5)$ & $672.1 \pm 39.0^{\mathrm{A}}(5)$ \\
\hline $\mathrm{NA}+\mathrm{MI} 50$ & $4.3 \pm 0.7^{\mathrm{B}}(8)$ & $86.0 \pm 16.3^{\mathrm{A}}(4)$ & $524.6 \pm 20.5^{\mathrm{A}}(4)$ \\
\hline $\mathrm{NA}+\mathrm{MI} 100$ & $5.9 \pm 1.1^{\mathrm{B}}(8)$ & $86.9 \pm 31.6^{\mathrm{A}}(4)$ & $666.9 \pm 41.4^{\mathrm{A}}(4)$ \\
\hline $\mathrm{NA}+\mathrm{MI} 500$ & $5.1 \pm 1.1^{\mathrm{B}}(7)$ & $85.8 \pm 10.7^{\mathrm{A}}(4)$ & $453.2 \pm 50.7^{\mathrm{B}}(4)$ \\
\hline
\end{tabular}

Prepubertal intact (day 18 of age) males were injected s.c. with of $50 \mu$ vehicle $(0$; control) or NA or NA plus antiprogestins for 15 days. Values are given as means \pm SEM. Values within a columm, which do not have the same upper case superscript $(A, B)$ differ significantly $(p<0.05)$. Numbers in parentheses indicate the number of the first inguinal mammary glands, or number of animals supplying seminal vesicles and spleen. Other details are given in the legend to Fig.1.

In prepubertal intact males, ON and MI had no significant effect on seminal vesicle weights in NA-treated animals. RU $(500 \mu \mathrm{g} / \mathrm{d})$, on the other hand, caused $63 \%$ increase in 
seminal vesicle weight in animals treated with NA at a daily dose of $12.5 \mu \mathrm{g}$ and caused $192 \%$ and $295 \%$ increase at doses of 100 and $500 \mu \mathrm{g} / \mathrm{d}$, respectively, in animals treated with $\mathrm{Na}$ at a daily dose of $25 \mu \mathrm{g}$.

Spleen weights of prepubertal intact males treated with NA at a daily dose of $12.5 \mu \mathrm{g}$ were not affected by simultaneous treatment with ON, RU and MI, whereas in animals treated with NA at a daily dose of $25 \mu \mathrm{g}$, spleen weights were decreased by the highest daily dose $(500 \mu \mathrm{g})$ of both RU (by 26\%) and MI (by 33\%).

In adult castrated males NA-stimulated $(12.5 \mu \mathrm{g} / \mathrm{d})$ mammary growth was inhibited by $\mathrm{ON}$ at a daily dose of $500 \mu \mathrm{g}$ by $76 \%$. RU caused $67 \%, 69 \%$, and $81 \%$ inhibitions of mammary growth at doses of 50,100, and $500 \mu \mathrm{g} / \mathrm{d}$, respectively. Mammary growth stimulated by a high dose of NA $(50 \mu \mathrm{g} / \mathrm{d})$ was decreased by RU and MI at daily doses of $50-500 \mu \mathrm{g}$ by $86-94 \%$ (Table 2).

Table 2. Effect of progesterone antagonists ON, RU and MI on NA-stimulated mammary gland and seminal vesicles growth in adult castrated $\mathrm{C} 3 \mathrm{H}$ male mice

\begin{tabular}{|c|c|c|c|}
\hline $\begin{array}{l}\text { Hormonal } \\
\text { treatment } \\
\left(\mu \mathrm{g} \cdot \mathrm{d}^{-1}\right)\end{array}$ & $\begin{array}{c}\text { The } \% \text { area of mammary fat } \\
\text { pad occupied by mammary } \\
\text { epithelial structures }\end{array}$ & $\begin{array}{l}\text { Seminal vesicle weights } \\
\text { (mg. } 100 \mathrm{~g}^{-1} \text { of body weight) }\end{array}$ & $\begin{array}{c}\text { Spleen weight } \\
\text { (mg. } 100 \mathrm{~g} \mathrm{~g}^{-1} \text { of body weight) }\end{array}$ \\
\hline 0 & $1.3 \pm 0.3(24)$ & $37.5 \pm 3.9(12)$ & $403.2 \pm 7.6(12)$ \\
\hline NA 12.5 & $7.2 \pm 1.2^{\mathrm{A}}(24)$ & $44.3 \pm 2.9^{\mathrm{A}}(12)$ & $395.9 \pm 31.6^{\mathrm{A}}(12)$ \\
\hline $\mathrm{NA}+\mathrm{ON} 500$ & $1.7 \pm 0.5^{\mathrm{B}}(6)$ & $21.5 \pm 1.7^{\mathrm{B}}(3)$ & $498.6 \pm 46.6^{\mathrm{A}}(3)$ \\
\hline NA 12.5 & $7.2 \pm 1.2^{\mathrm{A}}(24)$ & $44.3 \pm 2.9^{\mathrm{A}}(12)$ & $395.9 \pm 31.6^{\mathrm{A}}(12)$ \\
\hline $\mathrm{NA}+\mathrm{RU} 50$ & $2.4 \pm 0.4^{\mathrm{B}}(12)$ & $47.0 \pm 6.5^{\mathrm{A}}(6)$ & $410.1 \pm 27.9^{\mathrm{A}}(6)$ \\
\hline $\mathrm{NA}+\mathrm{RU} 100$ & $2.2 \pm 0.3^{\mathrm{B}}(10)$ & $83.1 \pm 8.5^{\mathrm{B}}(5)$ & $397.0 \pm 36.1^{\mathrm{A}}(5)$ \\
\hline $\mathrm{NA}+\mathrm{RU} 500$ & $1.4 \pm 0.4^{\mathrm{B}}(4)$ & $209.4 \pm 34.4^{*}(2)$ & $456.3 \pm 35.5^{*}(2)$ \\
\hline NA 50 & $37.6 \pm 2.8^{\mathrm{A}}(16)$ & $78.7 \pm 4.3^{\mathrm{A}}(8)$ & $456.8 \pm 36.9^{\mathrm{A}}(8)$ \\
\hline $\mathrm{NA}+\mathrm{RU} 50$ & $3.7 \pm 0.8^{\mathrm{B}}(8)$ & $109.7 \pm 10.2^{\mathrm{A}}(4)$ & $501.2 \pm 56.1^{\mathrm{A}}(4)$ \\
\hline $\mathrm{NA}+\mathrm{RU} 100$ & $3.2 \pm 0.8^{\mathrm{B}}(8)$ & $135.5 \pm 15.1^{\mathrm{B}}(4)$ & $497.2 \pm 20.3^{\mathrm{A}}(4)$ \\
\hline $\mathrm{NA}+\mathrm{RU} 500$ & $2.4 . \pm 0.7^{\mathrm{B}}(8)$ & $239.0 \pm 17.1^{\mathrm{B}}(4)$ & $715.9 \pm 161.1^{\mathrm{A}}(4)$ \\
\hline NA 50 & $37.6 \pm 2.8^{\mathrm{A}}(16)$ & $78.7 \pm 4.3^{\mathrm{A}}(8)$ & $456.8 \pm 36.9^{\mathrm{A}}(8)$ \\
\hline $\mathrm{NA}+\mathrm{MI} 50$ & $5.2 \pm 0.9^{\mathrm{B}}(10)$ & $80.6 \pm 7.3^{\mathrm{A}}(5)$ & $384.1 \pm 35.5^{\mathrm{A}}(5)$ \\
\hline $\mathrm{NA}+\mathrm{MI} 100$ & $3.1 \pm 0.7^{\mathrm{B}}(8)$ & $58.1 \pm 4.6^{\mathrm{A}}(5)$ & $453.8 \pm 35.5^{\mathrm{A}}(5)$ \\
\hline $\mathrm{NA}+\mathrm{MI} 500$ & $2.7 \pm 0.4^{\mathrm{B}}(10)$ & $70.6 \pm 3.1^{\mathrm{A}}(5)$ & $430.9 \pm 25.4^{\mathrm{A}}(5)$ \\
\hline
\end{tabular}

Animals were castrated at 30-35 days of age and administration of compounds begun 15-20 days after operation. * two animals from the group were excluded from the data set due to difficulties with seminal vesicle and spleen dissection resulting from the post-castration inflammatory reaction (peritonitis) Other details are given in Table 1.

Seminal vesicle weights were decreased by high doses of ON, increased by RU and not affected by MI. In animals treated with NA $(12.5 \mu \mathrm{g} / \mathrm{d})$, the daily $500 \mu \mathrm{g}$ dose of ON caused a $43 \%$ decrease in seminal vesicle weights, whereas RU exerted significant stimulatory effect of this variable and led to $88 \%$ and $393 \%$ increases at doses of 100 and $500 \mu \mathrm{g} / \mathrm{d}$, respectively (two animals from the group treated with $500 \mu \mathrm{g} / \mathrm{d}$ of RU were excluded from the data set due to difficulties with seminal vesicle dissection resulting from the post-castration inflammatory reaction). Similarly, in animals treated with a high dose of NA $(50 \mu \mathrm{g} / \mathrm{d}), \mathrm{RU}$ at daily dose 100 and $500 \mu$ g caused $72 \%$ and $204 \%$ increases in seminal vesicle weights, respectively.

Spleen weights of adult castrated males were not affected by treatment with antiprogestins. 


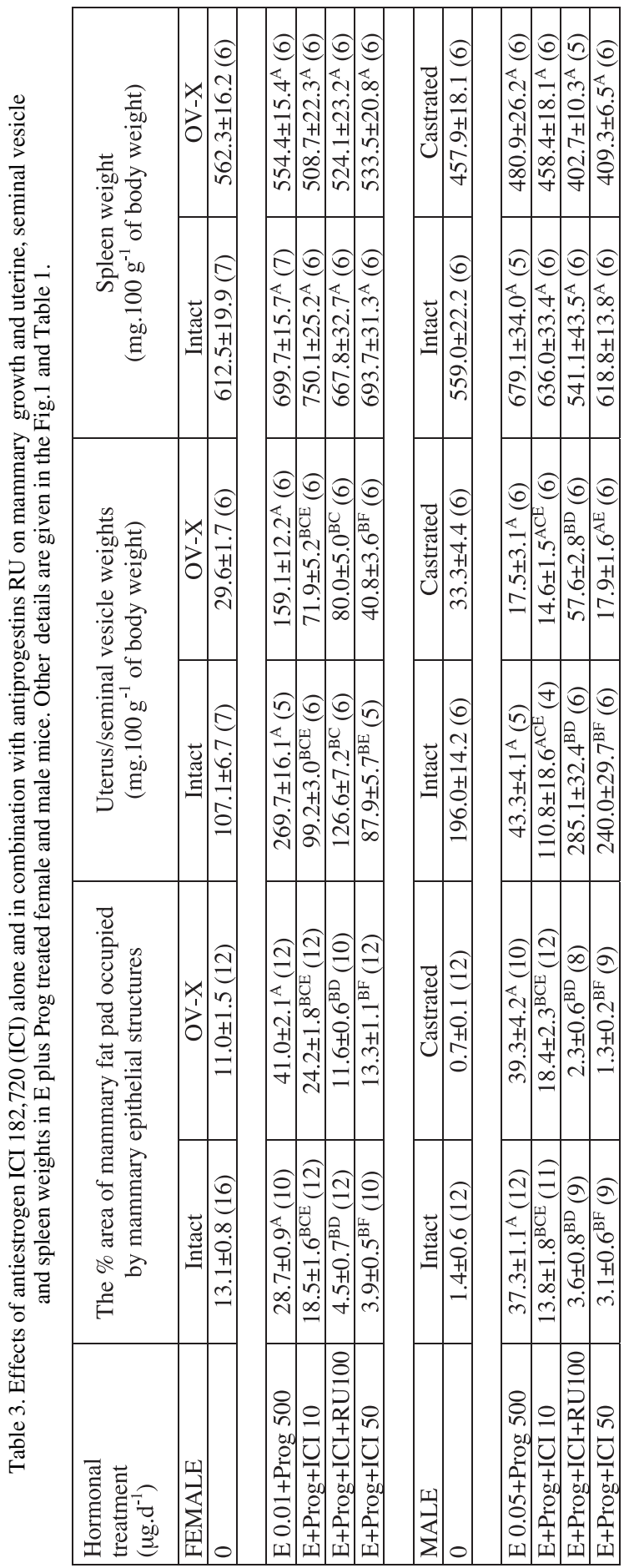

Effects of a combination of RU plus ICI

E $(0.01 \mu \mathrm{g} / \mathrm{d})$ plus Prog $(500$ $\mu \mathrm{g} / \mathrm{d}$ )-stimulated mammary growth was decreased by a submaximal daily dose of ICI $(10 \mu \mathrm{g})$ by $36 \%$ and $41 \%$ in prepubertal intact and adult OVX females, respectively. A combination of ICI and RU (100 $\mu \mathrm{g} / \mathrm{d})$ caused $84 \%$ and $72 \%$ decreases in E plus Progstimulated mammary growth in prepubertal intact and adult OVX females, respectively. However, the same level of inhibition of mammary growth was obtained by a high dose $(50 \mu \mathrm{g} / \mathrm{d})$ of ICI alone.

E plus Prog-stimulated uterine weight was significantly decreased by ICI at daily doses of $10 \mu \mathrm{g}$ and $50 \mu \mathrm{g}$ by $63 \%$ and $67 \%$ in prepubertal intact and by $55 \%$ and $74 \%$ in adult OVX females, respectively. A combination of ICI and RU had no effect on uterine growth in both prepubertal intact and adult OVX females (Table 3 ).

E $(0.05 \mu \mathrm{g} / \mathrm{d})$ plus Prog $(500$ $\mu \mathrm{g} / \mathrm{d})$-stimulated mammary growth was decreased by ICI $(10 \mu \mathrm{g} / \mathrm{d})$ by $63 \%$ and $53 \%$ in prepubertal intact and adult castrated males, respectively. A combination of ICI and RU caused $90 \%$ and $94 \%$ decreases in E plus Prog-stimulated mammary growth in young intact and adult castrated males, respectively. ICI alone at a high daily dose $(50 \mu \mathrm{g})$ had approximately the same effect on E plus Prog-stimulated mammary growth as the above mentioned combination of ICI plus RU.

ICI $(10 \mu \mathrm{g} / \mathrm{d})$ caused $156 \%$ increase in seminal vesicle weights of E plus Prog-treated prepubertal intact males. RU ( $100 \mu \mathrm{g} / \mathrm{d})$ acted synergistically with ICI to produce higher seminal vesicle weight 
(588\% increase) than that produced with a moderate dose of ICI alone. However, the high dose of ICI $(50 \mu \mathrm{g} / \mathrm{d})$ alone increased seminal vesicle weight by $454 \%$ that is not significantly different from that obtained by a combination of ICI plus RU. No such stimulatory effect of ICI was noted in seminal vesicles of castrated males.

\section{Discussion}

NA is a synthetic steroid exhibiting mainly progestational and estrogenic activities. In moderate doses $(12.5-25.0 \mu \mathrm{g} / \mathrm{d}$ in females and $50 \mu \mathrm{g} / \mathrm{d}$ in males) it acts in mice as a combination of a low dose of E and a high dose of Prog ( $\breve{S} \mathrm{karda} 2002 \mathrm{c}$ ), and thus, it was used to demonstrate the abilities of our in vivo model to detect not only antiprogestational and antiestrogenic activities of antiestrogens and antiprogestins, but also their other possible hormone agonistic, antagonistic or synergistic capabilities.

Unlike the available ER-antagonists that are highly receptor selective, the available PRantagonists also interact with the receptors for glucocorticoids, mineralocorticoids, androgens and estrogens (Philibert et al. 1989; Chwalisz et al. 1998; Sathya et al. 2002). The pure antiprogestational agent has not yet been synthetized. Two types of antagonists of the signal transduction pathway of Prog were developed and are currently being used for the treatment of a variety of endocrine-related disorders. Formally it was believed that Type I compounds failed to promote binding of PR to PREs whereas Type II antagonists did bind. Currently it is believed that Type I antagonist (e.g.ON) binds to PREs but promotes a conformational change distinct from that induced by Type II antagonists (e.g. MI or RU). The pharmacology of ON indicates that it is a more complete antagonist than MI. The cross-talk with cAMP signalling pathways potentiates the agonist activity of MI but has no effect on the biological activity of ON (Gass et al. 1998; Spitz 2003). The human PR- MI complex recognizes PREs and blocks the hormone-dependent transcriptional activation function of TAF-2 but not that of hormone-independent TAF-1, permitting the cell and promoter specific expression of partial agonist activity (Meyer et al. 1990).

MI (13ß- methyl-substituted antiprogestin) is known to possess strong antiprogesterone and antiglucocorticoid along with moderate antiandrogen properties. In search for more dissociated derivates, the hydroxy substituent and the propynyl group in position 17 of the MI was replaced by a spiroether group, which is known to induce specific affinity for the PR. Dimethyl amino group on the $11 \beta$-phenyl was replaced by methylthio group. The new derivative RU was about three times more active than that of MI for inducing abortion in rats and was devoid of any antiglucocorticoid activity on the thymus weight in rats. However, in contrast to MI, it has significant androgenic activity on rat prostate and also exhibits a slight progestomimetic activity on rat endometrial proliferation (Philibert et al. 1989, 1991; Chwalisz et al. 1998). ON is the $13 \alpha$-methyl-substituted antiprogestin that shares a number of structural similarities to MI; ON being less antiglucocorticoid than MI. In the rat uterus, it rapidly upregulates several genes normally under estrogenic regulation (Chwalisz et al. 1998). Prog is a major sex steroid controlling estrogen action in reproductive tracts and other estrogen-dependent tissues, therefore, it is not surprising that antiprogestins also interfere with various estrogenic responses. The antiproliferative effects of antiprogestins were not seen to the same degree in the uterus of E-treated OVX females of different species. MI and ON can block the ability of $E$ to increase endometrial growth in intact and OVX non-human primates and rabbits (Chwalisz et al. 1991; Burleigh et al. 1998). However, in E-treated OVX rats, ON and MI did not block E-stimulated endometrial growth, and luminal and glandular epithelium were stimulated more after antiprogestin plus $\mathrm{E}$, than after $\mathrm{E}$ alone. ON but not $\mathrm{MI}$ reduced E-stimulated myometrial proliferation and induced an overall uterine weight reduction (Chwalisz et al. 1998). Burleigh et al. 
(1998) showed that MI altered uterine weight only in rats receiving pharmacological doses of E. In NA-treated $(25 \mu \mathrm{g} / \mathrm{d})$ prepubertal (present results) and adult OVX female mice, uterine weights were not significantly affected by MI, however they were decreased by RU and $\mathrm{ON}$ at lower daily doses (50 $\mu \mathrm{g}$ in prepubertal females; $100 \mu \mathrm{g}$ in adult OVX females) and not affected by high $(500 \mu \mathrm{g} / \mathrm{d})$ dose. Based on these results, use of mouse uterine weight bioassay for screening and identification of antiprogestins is not recommended but it is still suitable for characterization of newly synthetized antiprogestins. Unlike MI, which in our experiments had no antiandrogenic activities measured according to seminal vesicle weights, RU displayed a full androgenic effect at a daily dose of $100 \mu \mathrm{g}$ and $500 \mu \mathrm{g}$ in both prepubertal and adult castrated male mice similarly as in the rat prostate (Philibert et al. $1989,1991)$. The fact that the same molecule of antiprogestin may also exhibit antiglucocorticoid (MI), androgenic (RU; RU 49295), antiandrogenic (MI) or progestomimetic (RU 49295) effects (Philibert et al. 1989, 1991) may explain variable responses of uterus and seminal vesicles to ON, MI and RU in our experiments. In the present experiments, the mammary gland was shown to be the most suitable tissue for the measurement of the antiproliferative potency of Prog antagonists in vivo. The bioassay depends on the inhibition of the well known stimulating effect of Prog on mammary duct lateral branching and on the formation of tubulo-alveolar buds, which are determined by highly sensitive morphometric analysis. RU was more active than MI as antiprogestin in the mammary gland of NA-treated prepubertal female and male mice. ON was not consistently more or less active than RU and MI. Similar results were obtained by Michna et al. (1991) in OVX rats.

However, for the measurement of the antiproliferative potency of antiprogestins it is essential to substitute the animals with Prog and estrogen (or NA), since the stimulating effect of Prog on the mammary gland is only induced when both hormones are given. The fact that the growth-stimulating potency of Prog necessitates the priming effect of estrogens suggests that antiestrogens should be able to decrease growth stimulating potency of Prog by blocking the priming effect of estrogen. Indeed, in our mouse models, E plus Prog-or NAstimulated growth of mammary epithelial structures was inhibited by both antiprogestins and antiestrogens. In fact, antiprogestins significantly inhibited the growth of mammary ducts in mice treated with $\mathrm{E}$ only (our unpublished results), although these compounds are known to have low or no affinity to the ER (Henderson 1987). These facts show that in vivo bioassay of antiprogestins is not fully specific but it may be verified by in vitro antiprogestin bioassay developed by Taylor et al. (1996). These authors developed a rapid method of screening anti-progestational agents in the primary culture system of virgin rat mammary epithelial cells grown in a serum-free medium on gels of rat tail collagen. In this culture conditions epithelial cells respond with a decrease in DNA synthesis that is dosedependent and reproducible over a wide dose range.

In the mammary gland of $\mathrm{E}$ plus Prog treated animals, RU acted additively with a submaximal dose of ICI to produce a lower growth rate than that observed in animals treated with ICI alone. However, uterine weights were decreased by ICI and not affected by further addition of RU. Such antiproliferative properties have importance with regard to treatment with antiestrogens and antiprogestins and implications for their potentional use for prevention and treatment of mammary and uterine cancers in human and veterinary medicine.

In conclusion, the measurement of antiproliferative potency of antiprogestins on the mammary gland of male and female mice treated with E plus Prog or NA is recommended for in vivo screening of antiprogestins. The other endpoints - uterine, seminal vesicle and spleen weights give only supplementary information on the other hormone agonist or antagonist activities of tested compounds. 


\section{Biologické účinky antiprogestinů v mléčné žláze, uteru a semenných váčcích prepubertálních a dospělých gonadektomovaných myší}

Předložená práce testuje a srovnává antiproliferativní a proliferativní účinky tří antiprogestinů na čtyřech myších modelech: prepubertální intaktní a dospělé ovariektomované (OVX) samice, prepubertální intaktní a dospělí kastrovaní samci. Norethindronem acetátem (NA, syntetický steroid vykazující progestagenní a estrogenní aktivity)-stimulovaný růst mléčné žlázy intaktních prepubertálních samic a samcủ byl snížen a to více antiprogestinem RU 46556 (RU) než antiprogestinem RU 38486 (MI) a onapristonem (ON). U dospělých OVX samic měl RU a MI nižší inhibiční účinek na NAstimulovaný růst mléčné žlázy než ON. Hmotnost dělohy nebyla ovlivněna MI, ale signifikantně snížena RU v dávce $50 \mu \mathrm{g} / \mathrm{d}$ u prepubertálních a v dávce $100 \mu \mathrm{g} / \mathrm{d}$ u dospělých OVX samic. Hmotnost semenných váčků nebyla ovlivněna MI, ale zvýšena RU jak u prepubertálních tak u dospělých kastrovaných samců. ON hmotnost semenných váčků snížil signifikantně u dospělých kastrovaných, nesignifikantně u prepubertálních samců. Estradiolem $17 \beta$ (E) plus progesteronem (Prog) stimulovaný růst mléčné žlázy byl snížen kombinací antiprogestinu RU (100 mg/d) s antiestrogenem ICI 182, 780 (ICI; $10 \mu \mathrm{g} / \mathrm{d}$ ) více než samotným ICI. Tento účinek lze charakterizovat jako aditivní, poněvadž vysokou dávkou samotného ICI $(50 \mu \mathrm{g} / \mathrm{d})$ bylo dosaženo stejného efektu jako kombinací RU plus ICI. Hmotnost dělohy jak prepubertálních tak dospělých OVX samic nebyla kombinací RU a ICI ovlivněna více než samotným ICI. Naproti tomu hmotnost semenných váčků byla aplikací ICI u prepubertálních samců a nikoliv u dospělých kastrovaných samců zvýšena. Předložené biostanovení je vhodným prostředkem pro detekci aktivit agonistů a antagonistů nově syntetizovaných analogů steroidních hormonů, přirozených a syntetických chemikálií a vzorků z vnějšího prostředí.

\section{Acknowledgements}

We are grateful to Eva Urbanová for excellent technical assistance, Professor F. Neumann (Schering AG, Berlin, Germany) for onapristone and Professor J.-P. Raymond (Centre de Recherches Roussel Uclaf, Romainville, France) for the gift of RU 38486 and RU 46556. This work was funded by the Grant Agency of the Academy of Sciences of the Czech Republic (Grant No. IBS 5045302 and 1QS 500450557) and Institutional Research Plan IAPG (No. AV0Z 50450515).

\section{References}

BURLEIGH DW, WILLIAMS RF, GORDON K, HSIU JG, HODGEN GD 1998: Screening for antiproliferative actions of mifepristone- differential endometrial responses of primate versus rats. Contraception 58: 45-50

CHWALISZ K, HEGELE-HARTUNG C, FRITZEMEIER KH, BEIER HM, ELGER W 1991: Inhibition of the estradiol-mediated endometrial gland formation by the antigestagen onapristone in rabbits: relationship to uterine estrogen receptors. Endocrinology 129: 312-322

CHWALISZ K, STOCKEMANN K, FRITZEMEIER KH, FUHRMANN U 1998: Modulation of oestrogenic effects by progesterone antagonists in the rat uterus. Human Reprod Update 4: 570-583

GASS EK, LEONHARDT SA, NORDEEN SK, EDWARDS DP 1998: The antagonists RU486 and ZK98299 stimulate progesterone receptor binding to deoxyribonucleic acid in vitro and in vivo, but have distinct effects on receptor conformation. Endocrinology 139: 1905-1919

GIANGRANDE PH, POLLIO G, MCDONNELL DP 1997: Mapping and characterization of the functional domains responsible for the different activity of the A and B isoforms of the human progesterone receptor. J Biol Chem 272: 32889-32900

HENDERSON D 1987: Antiprogestational and antiglucocorticoid activities of some novel $11 \beta$-aryl substituted steroids. In: Pharmacology and Clinical Uses of Inhibitors of Hormone Secretion and Action (Furr BJA, Wakeling AE eds.), London, Bailliere Tindall, pp. 184-211

HUFRIY A, KÖHLEROVÁ E AND ŠKARDA J 2003: Numbers of terminal end buds and ductal branchings as morphometric criteria for bioassay of activities of steroid hormone agonists and antagonists on the mammary gland. Acta Vet Brno 72: 483-491

KASTNER P, KRUST A, TURCOTTE B, STROPP U, TORA L, GRONEMEYER H, CHAMBON P 1990: Two distinct estrogen-regulated promoters generate transcripts encoding two functionally different human progesterone receptor forms A and B. EMBO J 9: 1603-1614 
KÖHLEROVÁ E, ŠKARDA J 2004: Mouse bioassay to assess oestrogenic and antioestrogenic compounds: hydroxytamoxifen, diethylstilbestrol and genistein. J Vet Med A 51: 209-217

KOTANOVÁ J, KÖHLEROVÁ E, ŠKARDA J 2005: Contrasting ability of steroidal (ICI 182780) and nonsteroidal (EM-800) antiestrogens to inhibit reproductive organ growth in male and female mice. Acta Vet Brno 74: $533-541$

MCDONNELL DP 1995: Unraveling the human progesterone receptor signal transduction pathway. Insights into antiprogestin action. Trends Endocrinol Metab 6: 133-138

MEYER M-E, PORNON A, JI J, BOCQUEL M-T, CHAMBON P, GRONEMEYER H 1990: Agonistic and antagonistic activities of RU 486 on the functions of the human progesterone receptor. EMBO J 9: $3923-3932$

MICHNA H, NISHINO Y, SCHNEIDER MR, LOUTON T AND EL ETREBY MF 1991: A bioassay for the evaluation of antiproliferative potencies of progesterone antagonists. J. Steroid. Biochem Molec Biol 38: 359-365

PHILIBERT D, COSTEROUSSE G, GAILLARD-MOQUILEVSKY M, NEDELEC L, NIQUE F, TOURNEMINE C, TEUTSCH G 1991: From RU 38486 towards dissociated antiglucocorticoid and antiprogesterone. In: Antihormones in Health and Disease. Front.Horm.Res., Karger Basel 19: 1-17

PHILIBERT D, HARDY M, GAILLARD-MOGUILEWSKY M, NIQUE F, TOURNEMINE C, NÉDÉLEC L 1989: New analogues of mifepristone with more dissociated antiprogesterone activities. J Steroid Biochem 34: 413-417

REVELLI A, MASSOBRIO M, TESARIK J 1998: Nongenomic actions of steroid hormones in reproductive tissues. Endocrine Rev. 19: 3-17

SATHYA G, JANSEN MS, NAGEL SC, COOK CE, MCDONNELL DP 2002: Identification and characterization of novel estrogen receptor-a-sparing antiprogestins. Endocrinology 143: 3071- 3082

SPITZ IM 2003: Progesterone antagonists and progesterone receptor modulators: an overview. Steroids 68 : 981-993

ŠKARDA J 2002a: Sensitivity and specificity of the bioassay of estrogenicity in mammary gland and seminal vesicles of male mice. Physiol Res 51: 267-276

ŠKARDA J 2002b: Sensitivity and specificity of bioassay of estrogenicity on mammary gland and uterus of female mice. Physiol Res 51: 407-412

ŠKARDA J 2002c: Norethindrone acetate and testosterone interactions in mammary gland, uterus and seminal vesicles of mice. Acta Vet Brno 71: 463-471

ŠKARDA J 2003: Bioassay of steroid hormone agonist and antagonist activities of anti-androgens on mammary gland, seminal vesicles and spleen of male mice. J Vet Med A 50: 204- 212

ŠKARDA J, KÖHLEROVÁ E 2006: Mouse bioassay for in vivo screening of oestrogen and progesterone antagonists. J Vet Med A 53: 145-153

TAYLOR JA, FORSYTH IA, WANG M-W 1996: Activity of progesterone and anti-progestins in a rat mammary primary cell culture system. J Steroid Biochem Molec Biol 58: 117-121

VEGETO E, SHAHBAZ MM, WEN DX, GOOLDMAN ME, O'MALLEY BW, MCDONNELL DP 1993: Human progesterone receptor A form is a cell- and promoter-specific repressor of human progesterone receptor B function. Mol Endocrinol 7: 1244-1255

WEI LL, HAWKINS P, BAKER C, NORRIS B, SHERIDAN PL, QUINN PG 1996: An amino-terminal truncated progesterone receptor isoform, PRc, enhances progestin-induced transcriptional activity. Mol Endocrinol 10: 1379-1387 